\title{
Effect of Green Tea (Camellia sinensis) Extract Feeding and Bedding Material on Growth Performance in Hamsters
}

\author{
Madhur $^{1}$, Harish Kr. Gulati ${ }^{1}$, Narender Singh ${ }^{1 *}$, Sushil Kumar ${ }^{2}$ and Sujoy Khanna ${ }^{1}$ \\ ${ }^{1}$ Department of Livestock Production Management, ${ }^{2}$ Department of Animal Nutrition, Lala \\ Lajpat Rai University of Veterinary and Animal Sciences, Hisar - 125 004, Haryana, India \\ *Corresponding author
}

\section{A B S T R A C T}

Keywords

Hamster, Green tea extract, Rice husk,

Saw dust, Sand, body weight gain

Article Info

Accepted:

16 February 2018

Available Online:

10 March 2018
Seventy two weaned Syrian hamsters of either sex were randomly assigned to six treatments in single cages $(290 \mathrm{~mm}$ X $220 \mathrm{~mm} \mathrm{X} \mathrm{140mm)} \mathrm{in} \mathrm{a} \mathrm{closed} \mathrm{room} \mathrm{where} \mathrm{the}$ temperature and relative humidity was maintained $24 \pm 50 \mathrm{C}$ and $60 \pm 15 \%$, respectively during the trial of 56 days. The experiment consisted of four dietary treatments. The concentrate mixture of all the groups was formulated using wheat, fish meal, ground nut cake, mineral mixture and common salt. Additionally, treatment group T2, T4 and T6 were provided with green tea extract. Green tea extract was prepared by inserting green tea bag $(1.3 \mathrm{~g})$ in boiling water in boiling water of volume $130 \mathrm{ml}$ so that effectively it formed 1 percent w/v solution. Our Study found that growth measurements for T2, T4 and T6 were better as compared to other treatment groups. This indicates the beneficial aspect of GTE. At the same time the growth profile is better for T2 because GTE in association with rice husk acted synergistically. Body weight gain for T2 in which GTE was provided was better as compared to other groups while it is minimum for T5 $(11.14 \mathrm{~g}$ vs $2.78 \mathrm{~g}, \mathrm{P}<0.05)$. Our Study found that growth measurements for T2, T4 and T6 were better as compared to other treatment groups. This indicates the beneficial aspect of GTE.

\section{Introduction}

During earlier days, when industrial revolution started, Mother Nature was able to clean all the waste generated. But as this pursuit of greed emboldened it was not possible for her to clean it up as it went beyond her carrying capacity. And then humans started acknowledging lethal repercussions like cancer. Coupled with this, due to artificial characters developed by humans, they are now more vulnerable to life style diseases and other behavioral problems.
In the wake of this, numerous researches started to analyze possible mechanism of action of diseases and there cure.

Since we cannot do researches directly on human beings due to ethical issues, so we needed animal models and here lies the importance of laboratory animals. Golden hamster or Syrian hamsters (Mesocricetus auratus) are now considered vulnerable. Their natural geographical range is limited to the north of Syria and the south of Turkey, in arid 
habitats. Their numbers have been declining due to loss of habitat caused by agriculture and deliberate destruction by humans. Albeit hamsters are the fifth most commonly used animal in research behind mice, rat, rabbit and guinea pigs, there are several reasons why the Syrian hamster is used in research. First of all, there is availability and ease of reproduction of hamsters; second, there relative freedom from naturally acquired disease; third, there susceptibility to many pathogens; fourth, there unique anatomic and physiologic feature; and fifth, there rapid development and short life cycle. Most of hamsters are used in cancer research, infectious disease research and behavioral studies (Susan V. Gibson).

Relatively few animal welfare studies have been conducted on Syrian hamsters (Mesocricetus auratus), despite the fact that considerable use is made of these animals in biochemical and behavioral research. Among the aspects of hamster welfare that have been studied so far are social housing (Arnold and Estep, 1990), cage floor preference (Arnold and Estep, 1994), cage dimensions, environmental enrichment (Reebs and Maillet, 2003), running wheels (Gebhardt et al., 2005; Reebs and St-Onge, 2005) and bedding material requirements for hamsters.

Captivity conditions must satisfy the basic needs of laboratory animals and ensure their physical, physiological and psychological welfare.

Bedding material is an important component of a laboratory animal's environment in captivity. It provides sanitary conditions by absorbing body wastes (Hauzenberger et al., 2006). Lanteigne and Reebs (2006) hypothesized that bedding material plays a major role in growth and welfare of hamsters by reducing the paw wounds. However, they noted no significant difference between pine shavings, aspen shavings and corn cob in their effect on wound number but growth performance was affected.

\section{Materials and Methods}

Seventy two weaned Syrian hamsters of either sex were randomly assigned to six treatments in single cages $(290 \mathrm{~mm}$ X $220 \mathrm{~mm}$ X 140mm) in a closed room where the temperature and relative humidity was maintained $24 \pm 5^{\circ} \mathrm{C}$ and $60 \pm 15 \%$, respectively during the trial of 56 days. The room had an exhaust fitting for ventilation and glass fitted windows and 6 CFL's (chloro-fluoro lamps) to maintain a light/dark cycle (approx. 14/10). The selected weaned hamsters were shifted to their allotted cages and allowed an adaptation period of 4 days. The concentrate mixture of all the groups was formulated using wheat, fish meal, ground nut cake, mineral mixture and common salt. Additionally, treatment group T2, T4 and T6 were provided with green tea extract (green tea taken was LIPTON, pure and mild). Green tea extract was prepared by inserting green tea bag $(1.3 \mathrm{~g})$ in boiling water in boiling water of volume $130 \mathrm{ml}$ so that effectively it formed 1 percent w/v solution (Table 2).

Feed ingredients used in the concentrate mixture formulation was analysed for proximate nutrients (AOAC, 2005), presented in Table 1. The hamsters under different treatments were fed concentrate mixture having minimum 17.5 percent protein and not less than 2.5 percent fat. The feed and water bottle in T1, T3 and T5 were provided separately to each hamster. Similarly in case of T2, T4 and T6 feed and green tea in water is provided. Water bottles were located near to the feeders and they were regularly cleaned to prevent the chance of any contamination. The study was carried out for a period of 56 days on selected hamsters.

Feed and water were supplied ad libitum throughout the experiment. Bedding material used for T1 and T2 was rice husk, for T3 and T4 was saw dust and for T5 and T6 was sand. Bedding material was changed every week. 
The hamsters were weighed and different body measurements were taken at the beginning of the experiment after providing an adaptation period of 4 days.

\section{Statistical analysis}

Statistical analyses were performed using the IBM SPSS statistics 20 software package for windows. The results were analyzed using the One-way analysis of variance and it was employed to determine the means along with standard error. Significant differences among the treatments means were determined using Duncan's test as per Snedecor and Cochran (1994). Level of significance was considered at $\mathrm{P}<0.05$.

\section{Results and Discussion}

\section{Growth performance}

The recorded data on body weight of hamster and body measurements (abdominal girth, body length, heart girth, hind foot length, ear length, tail length) of hamster under different treatments have been tabulated in Table 3 and 4 , respectively.

\section{Body measurements}

The results of average initial and final body measurements; and average increase in body measurements under different dietary treatments have been presented in Table 4 . The initial body weight of the hamsters under different treatments was found to be statistically similar. The corresponding means of initial body weight in treatment groups $\mathrm{T}_{1}$, $\mathrm{T}_{2}, \mathrm{~T}_{3}, \mathrm{~T}_{4}, \mathrm{~T} 5$ and $\mathrm{T} 6$ were $39.31,38.83$, 39.10, 38.83, 39.46, and $38.78 \mathrm{~mm}$ (Table 3). While the corresponding means of final body weight for $\mathrm{T}_{1}, \mathrm{~T}_{2}, \mathrm{~T}_{3}, \mathrm{~T}_{4}, \mathrm{~T} 5$ and $\mathrm{T} 6$ were 47.20, 49.97, 44.57, 47.07, 42.30 and 45.41 (Table 3). The result of study indicates that feeding of green tea extract had huge impact on body weight gain. At the same time, impact is more in case of $\mathrm{T} 2$ as it contained rice husk as bedding material, which proved to be the best one vis-à-vis sand and saw dust. Similarly, this is the case with rest of the parameters of body measurements also, such as heart girth, tail length, ear length, abdominal girth and body length.

Similarly, corresponding means of initial body length in treatment groups $\mathrm{T}_{1}, \mathrm{~T}_{2}, \mathrm{~T}_{3}, \mathrm{~T} 4, \mathrm{~T} 5$ and T6 were $120.32,120.23,120.20,120.39$, 120.39 and $120.34 \mathrm{~mm}$. While the corresponding means of final body length for $\mathrm{T}_{1}, \mathrm{~T}_{2}, \mathrm{~T}_{3}, \mathrm{~T}_{4}, \mathrm{~T} 5$ and T6 were $122.60,123.10$, 123.07, 122.49, 122.72 and 121.99 (Table 4).

The corresponding mean of initial abdominal girth in treatment groups $\mathrm{T}_{1}, \mathrm{~T}_{2}, \mathrm{~T}_{3}, \mathrm{~T} 4, \mathrm{~T} 5$ and T6 were 94.26, 94.13, 94.02, 94.16, 94.12 and 94.15. While the corresponding means of final abdominal girth for $\mathrm{T}_{1}, \mathrm{~T}_{2}, \mathrm{~T}_{3}, \mathrm{~T}_{4}, \mathrm{~T} 5$ and T6 were 96.37, 97.09, 96.36, 96.66, 95.63 and 96.70 (Table 4). The result of study indicates that feeding of green tea extract had impact on body length and abdominal girth parameters. At the same time, impact is more in case of $\mathrm{T} 2$ as it contained rice husk as bedding material, which proved to be the best one vis-à-vis sand and saw dust. Sand as a bedding material is not recommended.

Approximately same is the case with other body measurement parameters such as heart girth whose corresponding mean of initial and final readings for $\mathrm{T}_{1}, \mathrm{~T}_{2}, \mathrm{~T}_{3}, \mathrm{~T}_{4}, \mathrm{~T}_{5}$ and $\mathrm{T}_{6}$ were $89.62,89.31,89.91,89.92,90.43$ and 90.17 and 94.67, 95.38, 93.09, 94.21, 93.06 and 93.84 respectively (Table 4 ). For hind feet parameter, the initial and final values are $11.9111 .78,11.85,11.78,11.97$ and 11.77 and 14.31, 15.16, 13.52, 14.26, 12.81 and 13.77 respectively (Table 4$)$. 
Int.J.Curr.Microbiol.App.Sci (2018) 7(3): 1896-1902

Table.1 Proximate composition (\% DM basis) of the feed ingredients

\begin{tabular}{|l|l|c|c|c|c|c|}
\hline \multicolumn{1}{|c|}{ Sr. No } & $\begin{array}{c}\text { Name of } \\
\text { Ingredient }\end{array}$ & $\begin{array}{c}\text { Dry matter } \\
(\%)\end{array}$ & $\begin{array}{c}\text { Total ash } \\
(\%)\end{array}$ & $\begin{array}{c}\text { Ether } \\
\text { Extract } \\
(\%)\end{array}$ & $\begin{array}{c}\text { Crude } \\
\text { protein } \\
(\%)\end{array}$ & $\begin{array}{c}\text { Crude fiber } \\
(\%)\end{array}$ \\
\hline $\mathbf{1}$ & wheat & 91.01 & 2.45 & 2.67 & 10.40 & 2.34 \\
\hline $\mathbf{2}$ & Fish meal & 90.10 & 9.09 & 7.78 & 41.65 & 3.32 \\
\hline $\mathbf{3}$ & GNC & 89.89 & 7.58 & 4.60 & 46.32 & 6.01 \\
\hline
\end{tabular}

Table. 2 Chemical composition of concentrate mixture used for hamsters (\% DM basis)

\begin{tabular}{|l|c|}
\hline Attributes & Feed \\
\hline Dry matter & 90.93 \\
\hline Crude protein & 18.92 \\
\hline Ether extract & 3.27 \\
\hline Crude fiber & 3.8 \\
\hline Ash & 4.09 \\
\hline
\end{tabular}

Table.3 Body weight (g) of hamster under different dietary treatments (fortnightly)

\begin{tabular}{|c|c|c|c|c|c|c|}
\hline Days & T1 & T2 & T3 & T4 & T5 & T6 \\
\hline 0 & $39.31 \pm 0.67$ & $38.83 \pm 0.78$ & $39.10 \pm 0.68$ & $38.83 \pm 0.59$ & $39.46 \pm 0.68$ & $38.78 \pm 0.65$ \\
\hline $\mathbf{1 4}$ & $40.99 \pm 0.73$ & $40.9 \pm 0.89$ & $40.09 \pm 0.68$ & $40.56 \pm 0.67$ & $39.59^{\mathrm{a}} \pm 0.66$ & $40.3 \pm 0.72$ \\
\hline $\mathbf{2 8}$ & $43.08^{\mathrm{b}} \pm 0.75$ & $43.66^{\mathrm{b}} \pm 1.08$ & $41.65^{\mathrm{ab}} \pm 0.7$ & $42.41^{\mathrm{ab}} \pm 0.72$ & $40.40^{\mathrm{a}} \pm 0.64$ & $41.81^{\mathrm{ab}} \pm 0.76$ \\
\hline $\mathbf{4 2}$ & $45.06^{\mathrm{bc}} \pm 0.69$ & $46.73^{\mathrm{c}} \pm 1.12$ & $43.05^{\mathrm{ab}} \pm 0.68$ & $44.49^{\mathrm{bc}} \pm 0.71$ & $41.34^{\mathrm{a}} \pm 0.69$ & $43.97^{\mathrm{b}} \pm 0.62$ \\
\hline $\mathbf{5 6}$ & $47.2^{\mathrm{c}} \pm 0.68$ & $49.97^{\mathrm{d}} \pm 1.19$ & $44.57^{\mathrm{b}} \pm 0.63$ & $47.07^{\mathrm{c}} \pm 0.52$ & $42.3^{\mathrm{a}} \pm 0.68$ & $45.41^{\mathrm{bc}} \pm 0.59$ \\
\hline
\end{tabular}

Means with different superscripts row wise differ significantly $(\mathrm{P}<0.05)$. 
Table.4 Body measurements $(\mathrm{mm})$ of hamster under different dietary treatments recorded (fortnightly)

Mean \pm SE, $n=12$

\section{Abdominal girth}

\begin{tabular}{|c|c|c|c|c|c|c|}
\hline days & T1 & T2 & T3 & T4 & T5 & T6 \\
\hline $\mathbf{0}$ & $94.26 \pm 0.11$ & $94.13 \pm 0.18$ & $94.02 \pm 0.14$ & $94.16 \pm 0.15$ & $94.12 \pm 0.17$ & $94.15 \pm 0.13$ \\
\hline $\mathbf{1 4}$ & $94.61 \pm 0.13$ & $94.73 \pm 0.21$ & $94.53 \pm 0.13$ & $94.74 \pm 0.18$ & $94.48 \pm 0.21$ & $94.83 \pm 0.15$ \\
\hline $\mathbf{2 8}$ & $95.08^{\mathrm{ab}} \pm 0.13$ & $95.40^{\mathrm{b}} \pm 0.24$ & $94.99^{\mathrm{ab}} \pm 0.13$ & $95.30^{\mathrm{ab}} \pm 0.17$ & $94.85^{\mathrm{a}} \pm 0.22$ & $95.37^{\mathrm{ab}} \pm 0.15$ \\
\hline $\mathbf{4 2}$ & $95.65^{\mathrm{abc}} \pm 0.15$ & $96.23^{\mathrm{c}} \pm 0.31$ & $95.48^{\mathrm{ab}} \pm 0.14$ & $95.88^{\mathrm{bc}} \pm 0.19$ & $95.27^{\mathrm{a}} \pm 0.18$ & $96.00^{\mathrm{bc}} \pm 0.15$ \\
\hline $\mathbf{5 6}$ & $96.37^{\mathrm{b}} \pm 0.23$ & $97.09^{\mathrm{c}} \pm 0.36$ & $96.26^{\mathrm{b}} \pm 0.17$ & $96.66^{\mathrm{bc}} \pm 0.17$ & $95.63^{\mathrm{a}} \pm 0.21$ & $96.70^{\mathrm{bc}} \pm 0.14$ \\
\hline
\end{tabular}

\section{Body length}

\begin{tabular}{|c|c|c|c|c|c|c|}
\hline $\mathbf{0}$ & $120.32 \pm 0.1$ & $120.32 \pm 0.1$ & $120.20 \pm 0.07$ & $120.39 \pm 0.07$ & $120.39 \pm 0.07$ & $120.34 \pm 0.09$ \\
\hline $\mathbf{1 4}$ & $121.03 \pm 0.21$ & $121.03 \pm 0.21$ & $120.77 \pm 0.09$ & $120.69 \pm 0.05$ & $121.05 \pm 0.09$ & $120.68 \pm 0.13$ \\
\hline $\mathbf{2 8}$ & $121.72^{\mathrm{c}} \pm 0.2$ & $121.72^{\mathrm{abc}} \pm 0.2$ & $121.45^{\mathrm{a}} \pm 0.13$ & $121.23^{\mathrm{bc}} \pm 0.13$ & $121.68^{\mathrm{a}} \pm 0.08$ & $121.29^{\mathrm{ab}} \pm 0.13$ \\
\hline $\mathbf{4 2}$ & $122.10^{\mathrm{bc}} \pm 0.17$ & $122.10^{\mathrm{c}} \pm 0.17$ & $122.34^{\mathrm{ab}} \pm 0.16$ & $121.91^{\mathrm{bc}} \pm 0.03$ & $122.22^{\mathrm{a}} \pm 0.07$ & $121.58^{\mathrm{bc}} \pm 0.12$ \\
\hline $\mathbf{5 6}$ & $122.60^{\mathrm{b}} \pm 0.12$ & $122.60^{\mathrm{c}} \pm 0.12$ & $123.07^{\mathrm{b}} \pm 0.08$ & $122.49^{\mathrm{b}} \pm 0.08$ & $122.72^{\mathrm{a}} \pm 0.07$ & $121.99^{\mathrm{b}} \pm 0.16$ \\
\hline
\end{tabular}

\section{Heart Girth}

\begin{tabular}{|c|c|c|c|c|c|c|}
\hline $\mathbf{0}$ & $89.62 \pm 0.53$ & $89.31 \pm 0.51$ & $89.91 \pm 0.5$ & $89.92 \pm 0.52$ & $90.43 \pm 0.59$ & $90.17 \pm 0.41$ \\
\hline $\mathbf{1 4}$ & $90.60 \pm 0.51$ & $90.77 \pm 0.59$ & $90.65 \pm 0.45$ & $90.90 \pm 0.5$ & $91.05 \pm 0.51$ & $91.01 \pm 0.43$ \\
\hline $\mathbf{2 8}$ & $92.18 \pm 0.35$ & $92.48 \pm 0.68$ & $91.47 \pm 0.45$ & $92.04 \pm 0.37$ & $91.68 \pm 0.52$ & $91.99 \pm 0.36$ \\
\hline $\mathbf{4 2}$ & $93.35^{\mathrm{ab}} \pm 0.36$ & $93.86^{\mathrm{b}} \pm 0.54$ & $92.31^{\mathrm{a}} \pm 0.46$ & $93.17^{\mathrm{ab}} \pm 0.23$ & $92.21^{\mathrm{a}} \pm 0.46$ & $92.91^{\mathrm{ab}} \pm 0.25$ \\
\hline $\mathbf{5 6}$ & $94.67^{\mathrm{bc}} \pm 0.28$ & $95.38^{\mathrm{c}} \pm 0.47$ & $93.09^{\mathrm{a}} \pm 0.37$ & $94.21^{\mathrm{b}} \pm 0.2$ & $93.06^{\mathrm{a}} \pm 0.38$ & $93.84^{\mathrm{ab}} \pm 0.18$ \\
\hline
\end{tabular}

\section{Hind feetlenght}

\begin{tabular}{|c|c|c|c|c|c|c|}
\hline 0 & $11.91 \pm 0.21$ & $11.78 \pm 0.24$ & $11.85 \pm 0.21$ & $11.78 \pm 0.19$ & $11.97 \pm 0.21$ & $11.77 \pm 0.2$ \\
\hline 14 & $12.44 \pm 0.22$ & $12.39 \pm 0.27$ & $12.16 \pm 0.21$ & $12.30 \pm 0.21$ & $12.01 \pm 0.21$ & $12.22 \pm 0.22$ \\
\hline 28 & $13.06^{\mathrm{b}} \pm 0.23$ & $13.25^{\mathrm{b}} \pm 0.33$ & $12.63^{\mathrm{ab}} \pm 0.22$ & $12.87^{\mathrm{ab}} \pm 0.23$ & $12.26^{\mathrm{a}} \pm 0.2$ & $12.68^{\mathrm{ab}} \pm 0.23$ \\
\hline 42 & $13.67^{b c} \pm 0.21$ & $14.15^{c} \pm 0.34$ & $13.05^{\mathrm{ab}} \pm 0.21$ & $13.48^{b c} \pm 0.22$ & $12.52^{\mathrm{a}} \pm 0.21$ & $13.33^{b} \pm 0.19$ \\
\hline 56 & $14.31^{c} \pm 0.21$ & $15.16^{\mathrm{d}} \pm 0.37$ & $13.52^{\mathrm{b}} \pm 0.2$ & $14.26^{c} \pm 0.16$ & $12.81^{\mathrm{a}} \pm 0.21$ & $13.77^{\mathrm{bc}} \pm 0.18$ \\
\hline \multicolumn{7}{|c|}{ Ear length } \\
\hline$\overline{0}$ & $6.54 \pm 0.12$ & $6.51 \pm 0.14$ & $6.55 \pm 0.12$ & $6.49 \pm 0.11$ & $6.57 \pm 0.11$ & $6.46 \pm 0.12$ \\
\hline 14 & $6.81 \pm 0.14$ & $6.82 \pm 0.15$ & $6.71 \pm 0.12$ & $6.74 \pm 0.11$ & $6.57 \pm 0.1$ & $6.76 \pm 0.13$ \\
\hline 28 & $7.21^{b} \pm 0.12$ & $7.27^{\mathrm{b}} \pm 0.19$ & $6.95^{\mathrm{ab}} \pm 0.12$ & $7.12^{\mathrm{ab}} \pm 0.14$ & $6.71^{\mathrm{a}} \pm 0.1$ & $7.00^{\mathrm{ab}} \pm 0.13$ \\
\hline 42 & $7.51^{b c} \pm 0.12$ & $7.79^{c} \pm 0.19$ & $7.15^{\mathrm{ab}} \pm 0.12$ & $7.43^{b c} \pm 0.13$ & $6.92^{\mathrm{a}} \pm 0.14$ & $7.32^{b} \pm 0.11$ \\
\hline 56 & $7.91^{\mathrm{c}} \pm 0.11$ & $8.36^{\mathrm{d}} \pm 0.21$ & $7.47^{b} \pm 0.12$ & $7.84^{b c} \pm 0.09$ & $7.08^{\mathrm{a}} \pm 0.13$ & $7.62^{b c} \pm 0.11$ \\
\hline \multicolumn{7}{|c|}{ Tail length } \\
\hline 0 & $12.12 \pm 0.21$ & $12.18 \pm 0.26$ & $12.18 \pm 0.22$ & $12.16 \pm 0.2$ & $12.38 \pm 0.24$ & $12.16 \pm 0.2$ \\
\hline 14 & $12.82 \pm 0.23$ & $12.77 \pm 0.28$ & $12.58 \pm 0.22$ & $12.70 \pm 0.23$ & $12.40 \pm 0.23$ & $12.58 \pm 0.23$ \\
\hline 28 & $13.28^{\mathrm{ab}} \pm 0.23$ & $13.70^{\mathrm{b}} \pm 0.34$ & $13.01^{\mathrm{ab}} \pm 0.23$ & $13.25^{\mathrm{ab}} \pm 0.23$ & $12.65^{\mathrm{a}} \pm 0.22$ & $13.11^{\mathrm{ab}} \pm 0.24$ \\
\hline 42 & $13.98^{b c} \pm 0.24$ & $14.61^{c} \pm 0.35$ & $13.48^{\mathrm{ab}} \pm 0.22$ & $13.93^{b c} \pm 0.24$ & $12.89^{\mathrm{a}} \pm 0.2$ & $13.79^{b} \pm 0.2$ \\
\hline 56 & $14.58^{b c} \pm 0.21$ & $15.60^{\mathrm{d}} \pm 0.37$ & $13.93^{\mathrm{b}} \pm 0.2$ & $14.69^{c} \pm 0.16$ & $13.19^{\mathrm{a}} \pm 0.2$ & $14.19^{b c} \pm 0.19$ \\
\hline
\end{tabular}


In case of ear length, corresponding means of initial length in treatment groups $\mathrm{T}_{1}, \mathrm{~T}_{2}, \mathrm{~T}_{3}$, T4, T5 and T6 were 6.54, 6.51, 6.55, 6.49, 6.57 and 6.46. While the corresponding means of final length for $\mathrm{T}_{1}, \mathrm{~T}_{2}, \mathrm{~T}_{3}, \mathrm{~T}_{4}, \mathrm{~T} 5$ and T6 were 7.91, 8.36, 7.47, 7.84, 7.08 and 7.62 (Table 4).

For tail length, initial mean for $\mathrm{T}_{1}, \mathrm{~T}_{2}, \mathrm{~T}_{3}, \mathrm{~T}_{4}$, $\mathrm{T}_{5}$ and $\mathrm{T}_{6}$ were $12.12,12.18,12.18,12.16$, 12.38 and 12.16. While final values for $\mathrm{T}_{1}, \mathrm{~T}_{2}$, $\mathrm{T}_{3}, \mathrm{~T}_{4}, \mathrm{~T}_{5}$ and $\mathrm{T} 6$ were $14.58,15.60,13.93$, 14.69, 13.19 and 14.19 (Table 4). All these results indicate that green tea intake improved growth

\section{Body measurements}

The body measurements (body length, heart girth, abdominal girth, tail length, ear length and hind feet length) were almost similar at the start (Table 4). The average increase in body measurements (body length, heart girth, abdominal girth, tail length, ear length and hind feet length) are significantly higher $(\mathrm{P}<0.05)$ in $\mathrm{T}_{2}$ than other experimental groups $\left(\mathrm{T}_{1}, \mathrm{~T}_{3}, \mathrm{~T}_{4}, \mathrm{~T}_{5}, \mathrm{~T}_{6}\right)$. Thus the results reveals that hamster provided with $1 \%$ green tea extract (GTE) and rice husk as bedding material have higher average increase in all body measurements as compared to other treatments.

The higher body measurements increase also corresponds with higher average daily weight gain of same group. The final weight, total body weight gain and average daily body weight gain of hamsters provided with $1 \%$ green tea extract (GTE) and rice husk, saw dust and sand $\left(\mathrm{T}_{2}, \mathrm{~T}_{4}, \mathrm{~T}_{6}\right.$ respectively) as bedding material were found to be significantly $(\mathrm{P}<0.05)$ higher than hamsters reared under their respective control groups $\left(T_{1}, T_{3}, T_{5}\right.$ respectively). However there are paucity of literature available regarding bedding material we used in other countries and absolutely no literature available in India. Thus we can claim that it is a novel research conducted in India. In the study conducted by Blom et al., (1995) in mice they found that beddings consisting of relatively small particles $\left(\leq 1.2 \times 1.6 \mathrm{~mm}^{2}\right)$ were generally avoided, whereas beddings consisting of large fibrous particles were preferred. The results seem to indicate that size is one of the main determinants of the preference of bedding particles by laboratory mice and rats, and larger particles are preferred. So we can infer that rice husk is better as compared to saw dust and sand due to larger particle size. In our study we found that body measurements for $\mathrm{T}_{2}$ were significantly higher as compared to other treatments. Thus it can be inferred that GTE and rice husk as bedding material acted synergistically.

\section{Body weight changes}

The means of initial body weights of selected animals at weaning stage under treatments groups were found statistically similar (Table $3)$. The means of final body weight, body weight gain and average daily weight gain $(\mathrm{g})$ of hamster provided with $1 \%$ green tea extract (GTE) and rice husk as bedding material was found significantly higher at the end of experiment.

In this study the difference between the body weights gain between the groups could be caused by synergistic effect of GTE and rice husk as bedding material. However, Lanteigne and Reebs (2005) used pine shavings, aspen shavings; corn cob/wood pellets and found no significant effect of bedding material on body weight gain. Thus he suggested that none of the four bedding materials tested in this study can be judged to be inappropriate. But as they used completely different type of bedding materials thus further research is needed with the bedding materials we used in our study. 


\section{Acknowledgement}

The authors thank to Harish Kr. Gulati, Professor and Head, Department of Livestock Production Management, College of Animal Sciences, Lala Lajpat Rai University of Veterinary \& Animal Sciences, Hisar, for his kind cooperation and helpful suggestions.

\section{References}

Arnold C E and Estep D Q. (1990). Effects of housing on social preference and behaviour in male golden hamsters (Mesocricetus auratus). Appl. Anim. Behav. Sci. 27: 253-261.

Arnold C E and Estep, D. Q. (1994). Laboratory caging preferences in golden hamsters (Mesocricetus auratus). Lab. Anim. 28: 232-238.

Blom H J M., Van Tintelen G., Van Vorstenbosch C J A H V., Baumans V., Beynen A C. (1996). Preferences of mice and rats for types of bedding material. Lab Anim. 30: 234-44.

Gebhardt-Henrich S G., Vonlanthen E M. and Steiger A. (2005). How does the running wheel affect the behaviour and reproduction of golden hamsters kept as pets. Appl. Anim. Behav. Sci. 95: 199203.

Hauzenberger A R., Gebhardt-Henrich S G. and Steiger A. (2006). The influence of bedding depth on behaviour in golden hamsters (Mesocricetus auratus). Appl. Anim. Behav. Sci., 100: 280-294.

Lanteigne $M$ and Reebs S G. (2006). Preference for bedding material in Syrian hamsters. Lab. Anim. 40: 410418.

Reebs S G and Maillet D. (2003). Effect of cage enrichment on daily use of running wheels by Syrian hamsters. Chronobiol Int. 20: 9-20.

Reebs S G and St-Onge, P. (2005). Running wheel choice by Syrian hamsters. Lab. Anim. 39: 442-451.

\section{How to cite this article:}

Madhur, Harish Kr. Gulati, Narender Singh, Sushil Kumar and Sujoy Khanna. 2018. Effect of Green Tea (Camellia sinensis) Extract Feeding and Bedding Material on Growth Performance in Hamsters. Int.J.Curr.Microbiol.App.Sci. 7(03): 1896-1902.

doi: https://doi.org/10.20546/ijcmas.2018.703.225 